\title{
OTIMIZAÇÃO “IN LOCU” DO TRATAMENTO DE EFLUENTES DE FRIGORÍFICO MEDIANTE UTILIZAÇÃO DE ADITIVO BIOLÓGICO
}

Fernando Ryuiti Yonemura Matsuba*; Cassiana Maria Reganhan Coneglian.

Faculdade de Tecnologia/Campus I de Limeira.

\begin{abstract}
Resumo
A crescente industrialização no país consome elevada quantidade de água e gera elevada quantidade de resíduos sólidos e líquidos (efluentes), levando a problemas de poluição ambiental pelo despejo inadequado de efluentes nos corpos hídricos, isto é, sem que estejam de acordo com a legislação ambiental vigente. Dessa forma, o presente projeto teve como objetivo a otimização do tratamento biológico do efluente gerado em no frigorífico localizado na região de Piracicaba, SP. O efluente gerado é resultante do processo de abate de bovinos e suínos, e vem apresentando problemas no enquadramento nas concentrações de nitrogênio amoniacal, sendo estas superiores ao limite permitido por lei. O estudo avaliou a eficiência do aditivo biológico, denominado componente "E" no processo de estabilização da matéria orgânica, via tratamento biológico em lagoas aeradas, a fim de promover a nitrificação, com a diminuição das formas nitrogenadas, que impactam o corpo hídrico que recebe este efluente.
\end{abstract}

Palavras-chave: nitrogênio amoniacal, efluente, tratamento biológico.

\section{Introdução}

O abate de bovinos e suínos é uma atividade crescente que vem preocupando os ambientalistas devido a liberação de grande quantidade de matéria orgânica carbonácea e nitrogenada em corpos hídricos, ocasionando problemas ambientais (eutrofização de corpos hídricos) e modificação do ecossistema. Diante desta problemática, este projeto visou avaliar a eficiência do aditivo biológico (componente "E"), perante sua utilização e otimização no processo de remoção de nitrogênio amoniacal, no tratamento biológico do efluente lançado pelo Frigorífico e consequentemente assegurar que sejam respeitadas as normas propostas pelas resoluções Conama 357/2005 (BRASIL, 2005) e Conama 430/2011 (BRASIL, 2011).

\section{Resultados e Discussão}

$O$ projeto iniciou-se com a montagem de dois reatores com capacidade de $6 \mathrm{~L}$, contendo cada um $5 \mathrm{~L}$ de efluente oriundos do sistema de lagoas de estabilização da empresa em estudo, com aeração contínua. $O$ reator 1 (R1) continha apenas o efluente e no reator 2 (R2) adicionou-se $50 \mathrm{~mL}$ de aditivo biológico. Ambos permaneceram durante algumas semanas até a obtenção de biomassa ( 150 mg/L). Após a estabilização da biomassa nos reatores, realizou-se oito bateladas de tratamento biológico do efluente, com 24 horas de aeração, seguidas de 2 horas de decantação. No efluente tratado realizou-se análises físico químicas (temperatura, $\mathrm{pH}$, oxigênio dissolvido, alcalinidade e nitrogênio amoniacal) em triplicata, comparando-se o efluente bruto com o efluente tratado de R1 e de R2. Na Figura 1 estão descritos os resultados do nitrogênio amoniacal obtidos, no qual observa-se que as concentrações inicialmente encontradas no efluente bruto sofreram elevada diminuição quando tratadas nos reatores aeróbios e com a adição do componente "E". Ressalta-se ainda que para as análises do dia 04/07 realizou-se a troca de efluente nos reatores, o que não aconteceu com as análises do dia 19/06, o que explica o aumento da concentração de nitrogênio amoniacal.

Figura 1. Resultados do nitrogênio amoniacal

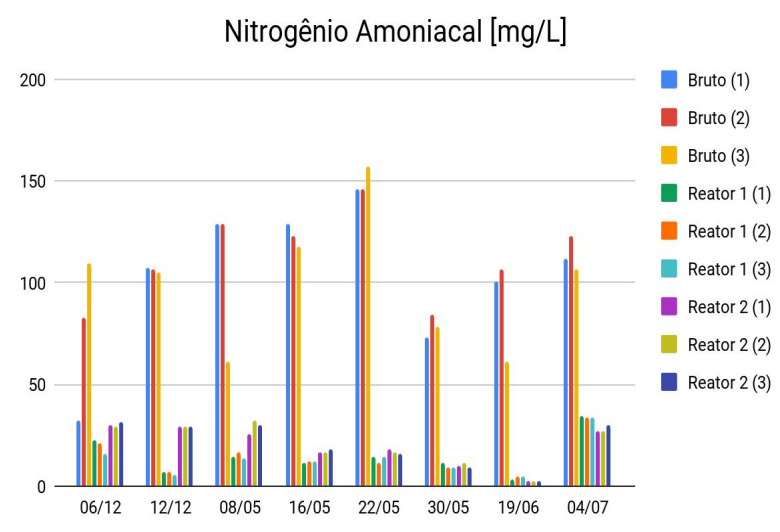

\section{Conclusões}

De acordo com os resultados obtidos, pode-se concluir que o tratamento proposto no projeto mostrou ser satisfatório e que de certa forma o aditivo biológico, componente "E", contribui para a remoção da carga orgânica nitrogenada presente no efluente do frigorífico; entretanto, vale lembrar que os resultados se apresentaram satisfatórios para escala laboratorial, enquanto que para a otimização "in locu" seria necessário avaliar a viabilidade de se realizar o tratamento nos pontos de descarte do efluente.

\footnotetext{
1 BRASIL. Conselho Nacional de Meio Ambiente. Resolução no 357, de 17 de março de 2005. Dispõe sobre a classificação dos corpos de água e diretrizes ambientais para o seu enquadramento, bem como estabelece as condições e padrões de lançamento de efluentes, e dá outras providências. Disponível em:

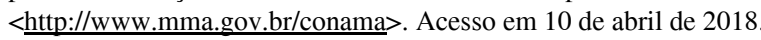

2 BRASIL. Conselho Nacional de Meio Ambiente. Resolução n ${ }^{\circ} 430$, de 13 de maio de 2011. Dispõe sobre as condições de lançamento de efluentes, complementa e altera a Resolução nº357, de 17 de março de 2005, do Conselho Nacional do Meio Ambiente. Disponível em: <http://www.mma.gov.br/conama> . Acesso em 10 de abril de 2018. 